\title{
Determinants of U.S. Foreign Policy foreign policy during the Cold War The Intra-American Perspective
}

\section{Determinanty polityki zagranicznej stanów Zjednoczonych w okresie zimnej wojny Perspektywa wewnątrzamerykańska}

\author{
Katarzyna Czornik*
}

\begin{abstract}
The U.S. accession to the Second World War and indisputable victory initiated a new stage in the history of the United States. The country took a superpower position next to the USSR. The USA became the leading force of the democratic and capitalist world. During the Cold War, competing with the Soviet Union for influence in the global scale, the United States effectively spread its ideology, political system model, and value system. A number of determinants of an internal nature, both objective and subjective, influenced the shape of the foreign policy of the USA during the Cold War.
\end{abstract}

Key words: The United States the Cold War, the foreign policy

\begin{abstract}
Abstrakt
Przystąpienie USA do drugiej wojny światowej i niepodważalne $\mathrm{w}$ niej zwycięstwo zainicjowało nowy etap w historii Stanów Zjednoczonych. Państwo to, które nie doznało zniszczeń na własnym terytorium, zajęło obok ZSRR pozycję supermocarstwa. W ładzie bipolarnym USA stały się wiodącą siłą świata demokratycznego i kapitalistycznego. USA zrezygnowały z polityki izolacjonizmu na rzecz globalnego zaangażowania. W okresie zimnej wojny, rywalizując o wpływy z ZSRR w każdym regionie świata, Stany Zjednoczone w sposób efektywny szerzyły promowaną przez siebie ideologię, model ustrojowy oraz system wartości. Taką możliwość stworzył Stanom Zjednoczonym szereg
\end{abstract}


determinant o charakterze wewnętrznym, zarówno obiektywnym, jak i subiektywnym, które wpływały na kształt polityki zagranicznej poszczególnych amerykańskich administracji w czasach zimnej wojny. Celem niniejszego artykułu jest zatem dokonanie syntetycznej analizy głównych, wewnętrznych uwarunkowań polityki zagranicznej Stanów Zjednoczonych w okresie funkcjonowania układu bipolarnego.

Słowa kluczowe Stany Zjednoczone, zimna wojna, polityka zagraniczna

\section{Introduction}

The nature of the conditions of the U.S. foreign policy during the bipolar system is reflected very well in the words of Henry Kissinger, who wrote:

$[\ldots]$ in every century there seems to emerge a country with the power, the will, and the intellectual and moral impetus to shape the entire international system in accordance with its own values. [...] In the twentieth century, no country has influenced international relations as decisively and at the same time as ambivalently as the United States. No society has more firmly insisted on the inadmissibility of intervention in the domestic affairs of other states, or more passionately asserted that its own values were universally applicable. No nation has been more pragmatic in the day-to-day conduct of its diplomacy, or more ideological in the pursuit of its historic moral convictions (Kissinger, 2002).

It is therefore indisputable that the decisions to abandon the nineteenth-century doctrine of the fifth American president James Monroe - the doctrine of isolationism and the U.S. entry into the war against the Axis powers, undertaken as a result of Japan's attack on Pearl Harbor in 1941, became an impetus for strengthening of global Pax Americana in the Cold War period (Michałek, 1993). This was undoubtedly the most serious challenge to American power, forces, means, and the will to engage globally that the U.S. had ever faced. In the decades that followed, the USA became a global power whose main goal in the period of bipolar rivalry was to defeat the competitive and expansive superpower of the USSR. After more than 40 years, this goal was fully achieved, which enabled America to pursue hegemonic objectives in foreign policy (U.S. Role, 2020). The United States owed its power to the dynamic growth of its economic and military potential, but also to the belief that the USA - as Andrzej Mania wrote - is a vehicle for values that it should promote (sometimes im- 
pose) for the good of the free world (Mania, 2019). Thus, at the beginning of the last decade of the 20th century, the USA gained the position of a hyperpower and entered a new stage of unipolar reality (Oezel, 2015) - thereby initiating the unilateral period (Krauthammer, 2002), in which the USA itself assumed the role of a solitary superpower (Huntington, 1999).

The aim of this paper is therefore to carry out a synthetic analysis of the main internal determinants of the U.S. foreign policy during the bipolar system. The paper discusses the major internal, objective and subjective determinants of the U.S. foreign policy during the two-block system, which influenced the foreign policy of individual American administrations (from the presidency of Harry Truman to the two terms of Ronald Reagan). The author attempts to answer the question what major intra-American determinants made it possible for the United States to assume the position of the only superpower at the end of the 20th century. Both the doctrinal sphere of different U.S. administrations is analyzed, as are the specific actions taken by these administrations, reflected in American foreign policy during the Cold War. The paper uses the following research methods: historical analysis, content analysis, as well as the comparative method.

\section{Determinants of foreign policy - theoretical aspects}

When analyzing the foreign policy of the United States during the bipolar system, it becomes indispensable to present the main terms related to this issue, such as foreign policy and its conditions (determinants, markers).

The theory of international relations assumes that foreign policy, which is also the internal policy of the state, reflects national interests, raison d'état, and the interests of internal social groups (Khara, 2018). There are feedbacks between domestic and foreign policy. Foreign policy therefore functions as an integral, albeit specific, part of state's policy (Horowitz, 1977). On the other hand, the implementation of a foreign policy depends on two groups of factors: the reaction of a polyarchic international environment and the potential of a given state. Drawing upon leading Polish researchers of international relations, it should be pointed out, following Teresa Łoś-Nowak, that foreign policy is a "dynamic process of formulating and implementing national interests in a polyarchal and polycentric international environment (Łoś-Nowak, 2000)". According to Erhard Cziomer:

[...] foreign policy is the process of formulating and implementing nationalstate interests in relation to other states and participants of the international system (Cziomer, 2001). 
Ryszard Zięba, on the other hand, wrote that

[...] foreign policy is a public purposeful activity of the state directed at the international environment (Zięba, 2004).

In turn, Roman Kuźniar emphasized that

the state's foreign policy should be understood as an organized and outward effort of the state, subordinated to the achievement of its vital interests, which is expressed in shaping its external environment (in creating and favoring relations and favorable situations, preventing and removing unfavorable). (Kuźniar, 2001).

It is also hard to disagree with Jacek Ziemowit Pietras, who stressed that the symbols of foreign policy for centuries were: a diplomat who was mildly convincing about his arguments and a general who was preparing the army to force concessions (Ziemowit-Pietraś, 1997).

A state's foreign policy is determined by a set of driving forces that initiate its operation at the international level. These forces, which are elements of the foreign policy environment, are synonymously referred to as: factors, markers, conditions, premises, determinants, stimulants, driving forces, incentives, or impulses to act or omissions in the international arena. In line with one of the definitions adopted in the theory of international relations, the notion of indicators of a state's foreign policy is understood as a system of mutually dependent conditions that cause a specific effect and are sufficient for a given effect to occur. However, the determinants of foreign policy are changeable and always closely correlated with each other. The literature provides various detailed classifications of this conceptual category, although a kind of conceptual consensus emerges about their general division into four main groups: 1) objective determinants - existing regardless of the state of activity and value judgement of policy makers; 2) subjective determinants - dependent on the activities of decision-makers, reflecting their assessments and preferences; 3 ) internal determinants - taking into account and reflecting the intra-state interests in relation to the international environment, especially the raison d'état, as well as specific factors, interests and internal conditions of the state; 4) external (international) determinants - reflecting the influence of the international environment on a state's foreign policy However, objective and subjective determinants have both the internal and external aspect (Zięba, 2004). Internal conditions take priority over external ones, and objective ones over subjective ones.

Therefore, referring in a very synthetic way to those four groups of determinants of a state's foreign policy, it should be emphasized that internal objective determinants relate primarily to: the geopolitical environment of the state (location, topography, climate, natural resources); its demographic potential (population number, age structure, population density, population growth rate, scale of migration, national composition); economic potential (GDP, currency strength, degree of economic ties with other countries); scientific and technical progress; the military strength of the state; the socio-political system (the 
administrative division of the country, the rights and obligations of citizens, the functioning of the media and public opinion, the influence of political elites and pressure groups, party system, social and professional structure). In turn, subjective internal determinants include: perception of the international environment (perception by both the establishment and society of a given country of other participants in international relations; culture and historical tradition of a given country; ideologies, religions, political views, belief systems and political consciousness as well as formulating a vision and strategy of foreign policy (the degree of social support and the possibility of consensus among politicians are important); the role of outstanding individuals (the degree of authority and the scope of their power); quality of the foreign service. On the other hand, the objective external determinants are: the evolution of the external environment (integration and globalization processes (Khara, 2018), the breakdown of states or the collapse of systems); the position of the state in the system of international relations and roles (depending on whether the state's position is central, key or peripheral, whether it is a power, a medium-sized state, a small state or a ministate); the nature of international legal agreements and obligations (including the degree of compliance with international law); participation in alliances, international organizations and obligations under the concluded bi- and multilateral agreements). The group of subjective external determinants includes: the international perception of a given state; concepts of foreign policy and military doctrines of other countries; diplomatic activity (declared and actual) of other participants in international relations (Cziomer, 2001).

\section{The main determinants of U.S. foreign policy during the Cold War of an objective nature}

After the Second World War, the United States and the USSR shaped a new international order known as bipolar (Ball, 1998). In the new order, these two superpowers effectively spread (imposed) socio-political and economic ideologies within their own spheres of influence, and competed at international level and in international space. A number of internal and external American conditions allowed the USA to take over the role of the leader of the democratic, capitalist world.

An analysis of the objective intra-American conditions should focus on the natural determinants that enabled the USA to assume the role of a superpower. Both the territorial size of the United States $\left(9,373,000 \mathrm{~km}^{2}\right)$ was important, which made it possible to place the USA in the fourth place among the largest 
countries in the world in terms of territoriality, after the USSR, Canada and the People's Republic of China (PRC) (Michałek, 2004), as well as the favorable geopolitical location of the USA - separation by the Pacific Ocean from Asia and the Atlantic Ocean from Europe, as well as sharing the border with just two countries (Canada to the north and Mexico to the south). For several centuries, this state of affairs predestined the United States to become one of the countries least endangered by external attacks in the world (German, 2002).

No less important was the evolving demographic structure of American society (Michałek, 2004) Comparing the data from the interwar period and the post-war period, a marked increase in the number of the U.S. residents should be noted, which is referred to as the demographic revolution. At the end of the 1940 s, the demographic potential of the USA was only $7 \%$ of the global population (Zyblikiewicz, 2004), but in the second half of that decade there was a significant increase in the birth rate known as the American Baby Boom. The constant growth of the American population allowed the USA to be ranked fourth among the most populated countries in the world during the Cold War, after the PRC, India and the USSR (Cole, 1968).

\section{Changes in the U.S. population during the Cold War}

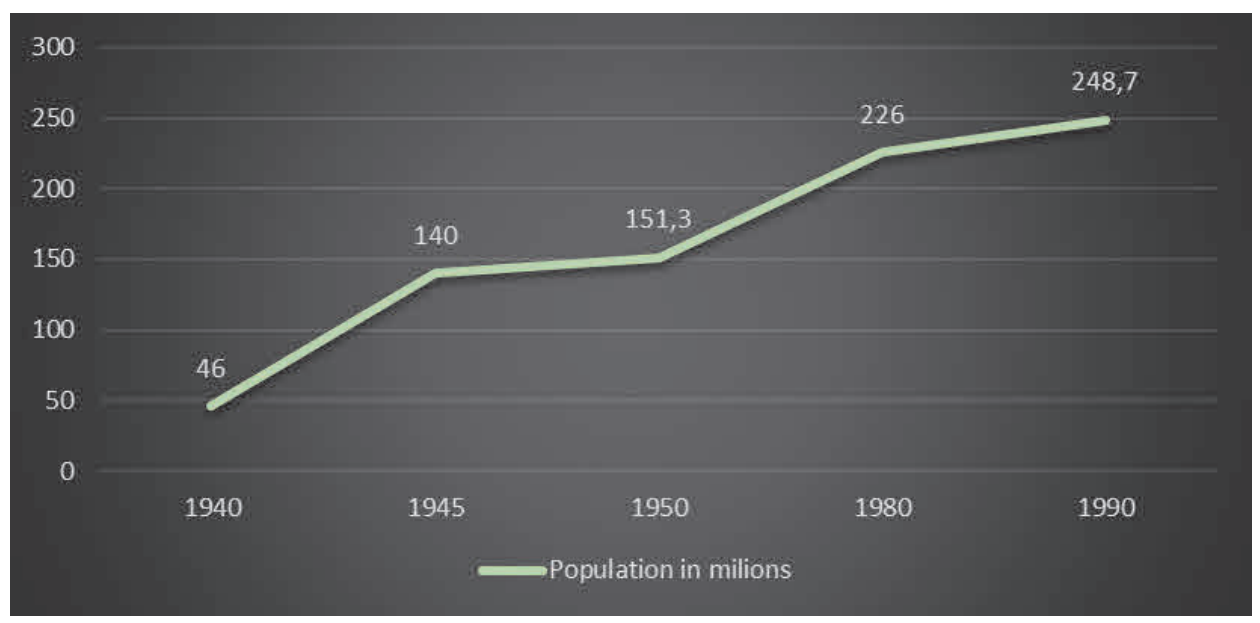

Source: Own study based on M.A. Jones, Historia USA, Gdańsk 2002, pp. 663-665.

In this respect, it should be added that migration processes played an important role in the evolution of the demographic structure of American society. Between 1940 and 1980, 11 million immigrants came to the United States, mostly from Central and Eastern Europe, Cuba, Mexico, and Canada (Growth, 2020).

Most importantly, after the Second World War, the USA also played a dominant role in the economic field. This state of affairs allowed the United States 
to conduct an effective global policy, to consolidate hegemony within its own area of influence, and to effectively compete in the arms race with the USSR (Kiwerska, 1999). As the Second World War ended, the United States emerged as an economic power, capable of commencing economic expansion into other third country markets (Higgs, 1994). Constantly increasing economic strength allowed the USA to take over the position that before the Second World War belonged to two European colonial powers - the United Kingdom and France (Pastusiak, 2005). The economic Pax Americana, shaped in the first years after the Second World War, was being perpetuated in the following decades in an effective manner. The USA took over the position of a creditor and main lender on a global scale (Bógdoł-Brzezińska, 2001). Although, in the second half of the 1940s, the United Kingdom, China and France were indicated as strategic partners of the USA in the economic field, which was supposed to reflect the concept of the "four policemen," but these predictions turned out to be premature. The USA made European partners dependent on itself by initiating the Truman doctrine, the Marshall Plan, or the establishment of the Organization for European Economic Cooperation (OEEC) (Lafeber, 1967). Furthermore, the USA became the guarantor of the stability of the currency system of most countries, which was reflected in the Breton Woods conference (July 1-22, 1944) at which it was decided that the U.S. dollar convertible into gold (in the proportion of USD35 per ounce of gold) would be the basis for calculating foreign exchange rates (Gaddis, 1997). In the second half of the 1940s, American banks held approximately $70 \%$ of all gold reserves in western countries. An expression of the ever-increasing American hegemony in the economic field was also the establishment of such organizations as: International Monetary Fund (IMF), International Bank for Reconstruction and Development (IBRD), or General Agreement on Tariffs and Trade (GATT), in which the United States, due to the financial contribution, had the deciding vote (Domagała, 2004). After the Second World War, American investors had the potential of about $3 / 4$ of the capital of other countries(McCauley, 2008). The U.S. share in world production alone was estimated at $41.4 \%$ in 1937 , and in the first year after the war, it was 62\% (Lastawski, 2004). Large corporations started to dominate in the USA, their domain was industrial production, there was an automotive boom (Chevrolet, Ford), the production of energy carriers and the service sector increased. The USA produced $57 \%$ of steel, $43 \%$ of electricity, $62 \%$ of oil, and $80 \%$ of cars globally. While the share of the USA in the exports of capitalist states before the war had been only $14.2 \%$, in the postwar period (in 1947) it already accounted for about $1 / 3$ of exports of the entire capitalist world (32.5\%).

Pointing to the endogenous objective determinants of the U.S. foreign policy during the Cold War, attention should also be paid to the constantly growing military power of the United States as well as the breakthrough scientific and technical advancement taking place in this country (Omitoogun, Sköns, 2007). 
This was possible due to the continuous increase in federal expenditure on national defense

\section{U.S. Cold War armaments expenditure in USD billions}

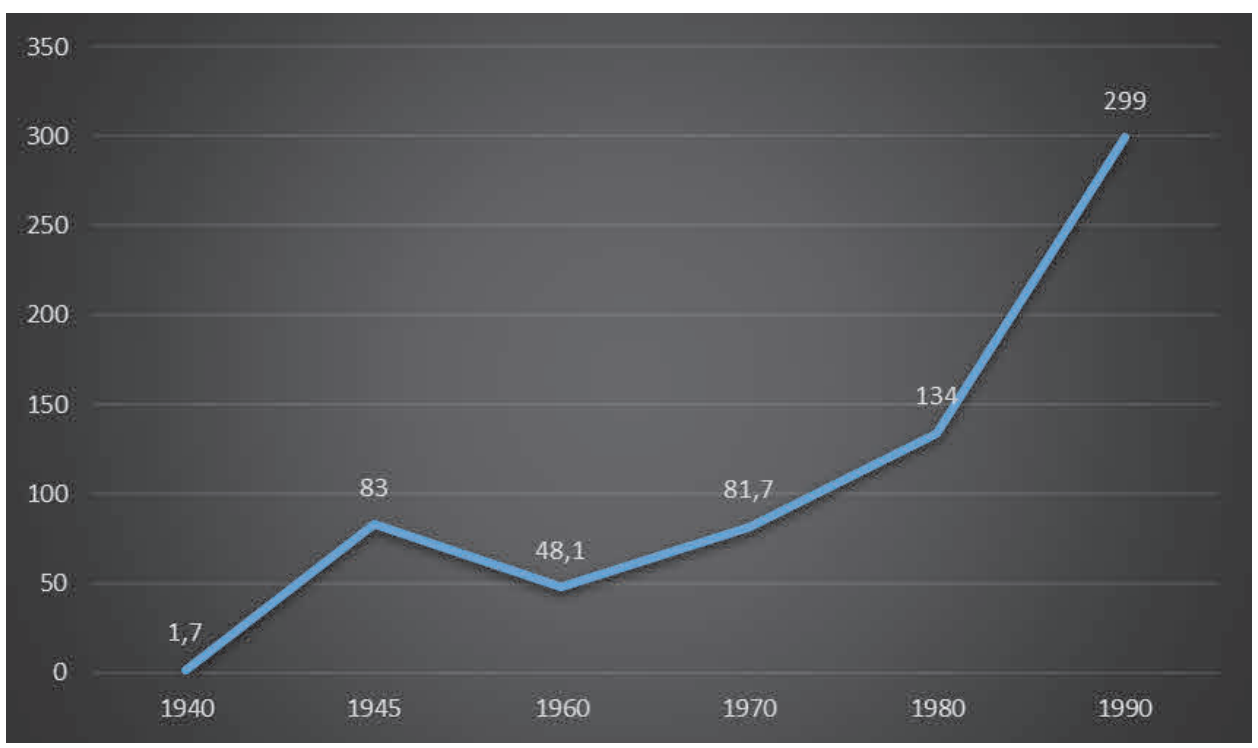

Source: Own study based on L. Zyblikiewicz, USA...,p. 223, p. 241; S. Perlo-Freemen, 65 years of military spending: Trends in SIPRI's new data, SIPRI, 21 November 2016, https://www.sipri.org/com mentary/blog/2016/65-years-military-spending (20.10.2020).

During the bipolar system, the American decision-makers also prioritized the development of the modern arms industry, including aviation and the navy. The foundation of the American military might was, on the one hand, the possession of nuclear weapons ("atomic diplomacy"), and on the other, the ability to move U.S. troops at maximum speed and with all equipment (Jaskuła, 2014). An extremely important element of the emerging military domination was the attempt to guarantee the presence of American forces in the strategic parts of the globe, which was to be served by the systematically expanded network of military bases. They served three basic functions: 1) military (they allowed the USA to keep its military forces in the territory of other countries, as close to the USSR as possible, thus creating the possibility of an attack on enemy territory, also during time of peace); 2) political (they made it possible to support anti-communist authorities in the countries where they were deployed); 3) economic (they allowed, on the one hand, to maintain good economic situation in the USA, and on the other, to link these countries and make them dependent on Washington) (Ohtomo, 2012). Before the war, the United States maintained bases on the American continent mainly, while abroad they were only in the Philippines, at the Guantanamo base in Cuba, and in the Panama Canal zone. 
In mid-1946, about 1.2 million U.S. soldiers were abroad, and in the early $1980 \mathrm{~s}$ the figure was 549,400 , which was $25 \%$ of all U.S. forces. The USA had over 1,500 bases (land, sea and air) as well as military installations and devices on the territory of 32 countries. At the beginning of 1969, the number of American bases was 2,400, of which about 700 were considered large (Herrera, Cicchini, 2013). In the 1960s, military bases were deployed in around 30 countries around the world. Until the outbreak of the Vietnam War, the USA attention was focused mainly on the European continent, with the Federal Republic of Germany constituting the main area of location for the U.S. armed forces (188 bases). An important role was also played by the military bases located in the Mediterranean region, bases in Greece and Turkey in particular, as well as bases in the Far East: Japan, South Korea, Taiwan, and Thailand. The U.S. naval forces then numbered: aircraft carriers -15 , aircraft $-1,778$, submarines -86 , support and security vessels - 237 .

During the James Carter administration, the American Intervention Force Rapid Deployment Force (RDF) was established. On January 1, 1983, they were subordinated to the newly created the U.S. Central Command, which was responsible for preparing troops to conduct combat operations on the territory of 19 African and Asian countries, especially in the Middle East, including the Persian Gulf sub-region, as well as Europe and Latin America (Cooley, 1991).

The USA power during the Cold War was also determined by advancements in the field of science and technology, including space exploration. The United States was a forerunner and promoter of new technologies, the home of the communication, rocket, transport, television, computer revolution and finally also the minicomputer revolution (Michałek, 2004). ${ }^{1}$

When analyzing the internal determinants of an objective nature of American foreign policy, one cannot ignore the socio-political and party system in the USA, political elites, the functioning of pressure groups and lobbies, or the enormous and constantly growing role of the mass media.

On the one hand, the U.S. Constitution does not provide expressis verbis who is responsible for conducting foreign policy, but on the other, in line with the checks and balance principle, specific for the U.S. political system, powers in the area of foreign policy have been divided between the president and Congress. The cooperation between the legislature and the executive power concerns, inter

${ }^{1}$ On May 5, 1961, the first American, Alan B. Shepard, flew into space on the "Freedom" spacecraft, which initiated a series of flights under the "Mercury," "Gemini," and "Apollo" programs, which ended on July 20, 1969 with the first landing on the moon of two crew members the Apollo 11 spacecraft - Neil Armstrong and Edwin Aldrin. Scientific and technical progress meant the development of the automotive and aviation industries. The launch of the first American four-engine jet - the Boeing 707, which was also used as the Air Force One presidential plane, was a major breakthrough. In 1963, the communication satellites Telstar 1 and Telstar 2 were launched into orbit. In 1953, the first credit card (Diner's Club card) was also introduced. 
alia, the use of the military abroad, the declaration of a state of emergency, the conclusion of international treaties and agreements, or the nomination process (Konstytucja, 2002). The U.S. president retains the initiative in formulating the foreign policy strategy, but Congress may take advantage of the opportunity to correct or block it. In practice, during the two world wars, the Korean War or the Indochina War, the initiative in international affairs belonged mainly to the President of the USA. Those were the so-called "imperial presidencies" of John F. Kennedy, Lyndon B. Johnson, and Richard Nixon (Bowles, 1998). It was not until the 1970s that the U.S. Congress became more active in the field of foreign policy (Berezowski, 2001), and its role in shaping foreign relations began to increase. During the Cold War, an important role in shaping U.S. foreign policy was also played by the lobby and pressure groups, which, using primarily a financial instrument, exerted influence over political decision-makers in order to implement their own interests. Almost every major professional, religious, ethnic, corporation, trade or industrial association had its own lobbyists. It has been estimated that there were approximately 7,000 lobbying firms in Washington during the Cold War (Davidson, Oleszek, 1994). In particular, the Jewish, Greek and Armenian lobbies stood out as the best organized and most effective (Bowles, 1998).

Therefore, to close the objective analysis of the intra-American determinants of foreign policy, a reference should also be made to the functioning of the media and public opinion in the USA, which is called the fourth power in the country, and with reason (Hofman, 2009). It was after the Second World War that the influence of the former group became most visible in relations between society and politics. For it is the mass media that, for example: first created, and then destroyed Senator McCarthy; promoted the ideal John F. Kennedy, and after his death they created the myth of a great political personality; compromised and helped to remove Richard Nixon from power (Watergate) (Kutler, 1994); made the public to withhold their assent to the Vietnam War; portrayed President Gerald Ford as a heavy-handed and incompetent politician; created the ever-smiling James Carter, then destroyed that image by showing a picture of the president fainting while jogging; promoted actor by profession Ronald Reagan; or during the Second Gulf War, manifested uncritical support for President George H. Bush (Skurowski, 1997). American media, in line with the principle of freedom of speech and the media, which is an overriding precept in the USA, for their own use and in accordance with their own political convictions, without any objections or compromise created images of strong and weak politicians, and bearing in mind the extremely difficult time of the Cold War, potential military conflict with the USSR and necessity to defeat the communist enemy, constantly built the image of a seemingly united American political scene and the monolithic American society centered around traditional American symbols and the omnipresent sense of patriotism. 


\section{The main determinants of US foreign policy during the Cold War of a subjective nature}

The shape of the United States' foreign policy during the bipolar order was significantly influenced by the internal conditions of a subjective nature. The determinants that enabled the USA to maintain its position as a superpower during the Cold War were the perception of the evolving international environment and the adaptation of the foreign policy to the changing conditions, the influence of ideology, religion, political awareness, and the role of charismatic individuals. Those factors further exerted their influence after the U.S. victory in the Cold War rivalry.

When analyzing the determinants outlined above, it should be emphasized that during the Cold War period, one of the most important determinants of the U.S. foreign policy was the area of framing foreign policy strategies. This was all the more important that the American foreign policy almost from the moment of the state constitution was characterized by a dilemma based on the answer to the question which direction would bring more benefits to the United States, isolationism or involvement? (Kiwerska, 1995) ${ }^{2}$ In the period of rivalry with the USSR, the choice of the option of getting involved and defending the Western world against the expansion of communism seemed obvious.

During the bipolar order, there was a social consensus in the United States regarding the goals and main course of foreign policy. Supporters of various political options focused essentially around two pillars, which were to counter and deter the USSR (Mania, 2019). Only in the second half of the 1960s, there was a significant revaluation in this matter. The reasons for the changes should be sought in the political and psychological prerequisites of the Vietnam War, the post-Vietnamese syndrome, the changes taking place in the American establishment caused, among others, by the Watergate scandal, the CIA and FBI scandals, and the emerging slogans of moral renewal in political life. Thus, in the first half of the 1970s, different positions on the way of conducting American foreign policy were developed. They were characterized, on the one hand, by caution and skepticism as regards the USA taking on military obligations abroad, and on the other, by placing the emphasis on competing with the USSR, with the possibility of cooperating with it in selected areas.

The USA, emerging from the Second World War as the undisputed military, political and economic power, made a fundamental shift in the foreign policy.

${ }^{2}$ In 1911, Alfred Mahan formulated the idea of American expansionism - mastering water spaces and becoming the first power in the world. A few years later, General William Mitchell assigned crucial importance to the US Air Force. Based on these two theories in the 1960 s, the global strategy of the United States was shaped, the aim of which was to remove the threat of war from the territory of the USA. 
Concerns about a return to the policy of isolationism that surfaced in the mid1940s turned out to be unfounded. After the Second World War, luminaries such as George Marshall, Averell Harriman, Dean Acheson, James Forrestal, John Foster Dulles, George Kennan and Dean Rusk took steps to promote the global involvement of the United States (Zyblikiewicz, 2004). The break-up of cooperation within the Great Coalition during the Second World War and rivalry with the USSR therefore implied the emergence of a new, global U.S. doctrine, known as the containment doctrine, which set the course of American foreign policy in the years 1947-1952. Its creator, George F. Kennan, the then counselor of the U.S. embassy in Moscow, wanted the USA and Western European countries to create an effective barrier against the spread of communist ideology in the world, thus forcing the socialist bloc to make political concessions. According to the doctrine, the USA was to become involved wherever there was a threat of a victory for communism. The containment doctrine was supposed to bring about a balance of power between superpowers on a global scale. The United States was to focus on Western Europe as the most likely battle front. The leading instruments for implementing the doctrine in practice were: the Marshall Plan, the Truman Doctrine, the rise of West Germany and NATO, as well as the formation of numerous military alliances (McCauley, 2008). The implementation of the containment doctrine meant a definite departure from the assumptions of isolationism, marking new levels of global involvement of the United States.

In 1952, the U.S. presidential election was won for the first time in twenty years by Republican candidate Dwight Eisenhower, who, by criticizing the containment doctrine as too soft, gained broad support from the American public. The new secretary of state, John Foster Dulles, who was the architect of the liberation doctrine, implemented its principles. The doctrine was based on the assumption that the USA as a superpower should lead to the liberation of the world from the ideology of communism. Dulles called for the formation of a strong coalition of Western democracies capable of resisting the expansion of the USSR (LaFaber, 1967). Any conflict on the East-West line could be resolved by the USA using all possible means, balancing on the brink of war. According to the assumptions of the liberation doctrine, it was only after the strengthening of Western Europe that the negotiations with the USSR on détente had a chance of success. Western Europe and maintaining strong ties with Germany remained the priority and the basis of the U.S. global security policy (Ambrose, 1993). ${ }^{3}$ In

${ }^{3}$ President Dwight Eisenhower was in favor of accelerating the process of Germany's remilitarization within NATO, as well as he strived to limit communist influence in the socalled then the Third World, as exemplified by the CIA intervention in Iran in 1953; actions against the government of Arbenzov in Guatemala in 1954; or the attempt to overthrow Fidel Castro in Cuba in 1961. In the case of Indochina, Eisenhower advocated the consolidation of non-communist forces in the region and the withdrawal of France, thus avoiding direct US 
1954, the foundations of the liberation doctrine were modified as part of the roll back doctrine - pushing back Soviet influence from Eastern Europe. It was assumed that communism should be pushed to the borders of the USSR. In 1957, both concepts collapsed, which was due to: the Suez crisis of 1956; uprising in Hungary in 1956; the USSR launch of the first Sputnik into space in October 1957; the death of Joseph Stalin in 1953, and the related policy of détente in theUSA-USSR relations (Malendowski, 1994)

The successor of President Dwight Eisenhower, John F. Kennedy from the Democratic Party, still as a candidate for the U.S. presidency, described his political program as "New Frontier," referring to the legacy of Franklin Delano Roosevelt (Zyblikiewicz, 2004). He declared to strengthen the position and prestige of the USA in the international arena (Kissinger, 2002). The goal of his administration, like that of his predecessors, was to eliminate communism, but the measures leading to this were to be of a peaceful nature (Pastusiak, 2005) Following the April 1961 incident in the Bay of Pigs, and subsequent Cuban quarantine, the USA recognized the principle of the balance of power in international relations. John F. Kennedy sought to win over anti-American countries, then so-called the Third World, and therefore in 1961 proposed the "Alliance for Progress" - a program of economic and social development in Latin America. Kennedy also established the "Peace Corps" - an organization to train local staff and send volunteers to developing countries. These actions were aimed at stopping the infiltration of the USSR in the so-called Third World (Bartlett, 1997).

Importantly, Kennedy's successor, President Lyndon Johnson in dealing with the Eastern Bloc continued the political line of his predecessor to a large extent (Brzeziński, 1966) ${ }^{4}$ Both Kennedy's and Johnson's strategies were characterized by dualism - a tendency to seek a rapprochement with Moscow while pursuing a policy of force and containment of the USSR (Bankowicz, 2004) The Johnson doctrine, announced on May 2, 1965, predestined the USA to the role of the world's policeman. It indicated that the USA would not allow the communists to seize power in any of the countries of the Western Hemisphere (Dobrzycki, 2000). ${ }^{5}$ As emphasized, the USA had the right to intervene wherever its interests were at stake. The foreign policy of the Lyndon Johnson administration was therefore dominated by the ongoing problem of American involvement in the Vietnam War, the consequences of which were felt in the USA in many areas over the next decades.

involvement in the war in Indochina. He saw the best security for U.S. interests in Southeast Asia in the creation of SEATO.

${ }^{4}$ Lyndon Johnson, like John F. Kennedy, promoted the concept of building bridges in relations with the Eastern Bloc.

5 1965, U.S. troops intervened in the Dominican Republic. 
The unresolved problem of the U.S. involvement in Southeast Asia became the main challenge of the next Richard Nixon administration. Henry Kissinger's and Melvin Baird's strategy of war "Vietnamization," namely conducting peace negotiations and replacing American troops with South Vietnamese forces, became a leading element of the Nixon doctrine announced on the island of Guam on July 25, 1969. The USA was to remain a global power, whose nuclear potential, naval and aviation forces were to guarantee the security of Japan and Southeast Asia, but land defense should have remained the competence of the countries in the region (Kiwerska, 1999). ${ }^{6}$ As it was emphasized, the USA should become involved only where its national interests were directly threatened, giving up the role of a global policeman. The conviction that American power is limitless has been replaced by the awareness of its limitations. In relations with the USSR, pragmatism won over American messianism. The administration of Richard Nixon, and then Gerald Ford, recognized the ineffectiveness of conducting politics from a position of strength in the evolving international environment. Proposals to replace the era of confrontation with the era of negotiations, with the idea of partnership, disarmament and peaceful coexistence have become dominant.

The concept of the foreign policy of the next U.S. president, James Carter, can be described as a departure from the global doctrine. However, the implemented strategy turned out to be a set of not fully compatible assumptions, among which five prevailed: strengthening the political and economic cohesion of the countries of the Western bloc (Tripartite Commission, trilateralism); promoting constructive cooperation with developed countries (especially with influential countries such as Brazil, Saudi Arabia, India, and Nigeria); continuing the dialogue and increased diplomatic, economic and military activity to resolve the Middle East conflict - promoting the success of the agreement between Egypt and Israel concluded at Camp David in 1978, and normalizing the situation in Iran as a result of the Islamic revolution (Korany, 1992) - the overthrow of the pro-American Shah Mohammad Reza Pahlavi and the hostage crisis (Tousi, 1997); protection of U.S. strategic interests, with particular focus on the Southeast Asia region; continuing the process of arms control and détente (Holzer, 2000) For the administration of President Carter, the protection of human rights and the related restoration of the moral authority of the USA in the world, which was seriously undermined as a result of the Watergate and Iran-Contras scandals (Cordesman, 1987) and the long-term implications of involvement in the Vietnam War were of particular importance.

${ }^{6}$ The withdrawal of 550 thousand American soldiers from Vietnam started in June 1969. On January 27, 1973, a peace treaty was signed providing for the withdrawal of U.S. troops from Vietnam. The Vietnam War cost the USA USD 165 billion. The main goal of stopping communism in Asia was not achieved, though. 
James Carter's successor, Ronald Reagan, took the office as President of the United States during a period of increasing tensions between the superpowers. In 1979, the era of détente ended, which was decisively influenced by the double missile decision and the USSR's invasion of Afghanistan (Halliday, 2005). Ronald Reagan devoted his first term of office to the confrontation with the USSR and the second term to disarmament negotiations, which resulted in the disintegration of both the Eastern Bloc and the collapse of the USSR (Hanhimäki, Westad, 2003). ${ }^{7}$ Ronald Reagan was of the opinion that the USA, as a result of the Vietnam War and the loss of one of the most important allies in the Middle East (Tarock, 1998) - Iran (the failure of the twin pillar policy), was weakened as the world leader and thus the U.S. power and hegemony needed to be rebuilt (Nowik, 1985). The foundation of Reagan's doctrine was the Pentagon's concept of U.S. military involvement in conflicts in then so-called the Third World, which were referred to as low-intensity conflicts. The doctrine envisaged three forms of U.S. military involvement abroad: helping to counter uprisings against conservative leaders; support for anti-government forces in progressive countries (Leczowski, 1990); active defense against terrorism. In the late 1980s, however, the Reagan administration began to perceive the international system in terms of change which overlapped with a number of external conditions shaping the international arena. The following have become dominant in this matter: the energy crisis (Stivers, 1986); the Arab oil embargo of 1973-1974 (Kokxhorn, 1976); détente processes; disintegration of the two-block system; downplaying American and Soviet hegemony in their own spheres of influence; the USA defeat in Vietnam; failure of the USSR in Afghanistan; postulates of a new economic order; the emergence of a pentagonal world, and the emerging theories about imminent decline of U.S. power and about building a polycentric world.

To sum up the subject of American administrations' strategies during the Cold War, the words of Samuel P. Huntington seem to be the most appropriate, as he pointed that the United States is a vast country with an array of civilizational and cultural factors which should be accounted for while building American military strategy (Huntington, 1986).

Therefore, when analyzing the intra-American determinants of foreign policy, attention should also be paid to military doctrines, the basic axiom of which, unchanged over time, was the desire to exclude the U.S. territory from the reach of possible military operations.

7 In the 1980s, the strategy of Ronald Reagan's foreign policy underwent a major revaluation. Starting with the perception of the USSR in terms of an "evil empire," permanent increase in defense spending, expansion of the armaments program, providing aid to anticommunist movements in Afghanistan, Angola, Ethiopia, Cambodia, Nicaragua, the invasion of Grenada in October 1983 (intended to limit the influence of the USSR and Cuba in the Caribbean region), up to the period of perestroika and the agreements with Mikhail Gorbachev. 
In 1954, the first post-war American military doctrine, known as the "shield and sword," was officially proclaimed. It was based on the assumption that the USA should have a decisive advantage over the USSR in terms of both nuclear weapons stocks and their means of delivery. As indicated, any armed conflict between the USA and the Warsaw Pact states could automatically turn into a global nuclear war. The situation in which the U.S. territory became directly open to attack triggered a shift in thinking among the American political elite. The new military and political reality led to the modification and creation of the doctrine of flexible response in 1962. Its assumptions were dominated by the conviction that three types of war could be waged: universal - with unlimited use of nuclear weapons; limited - mainly conventional, with the possibility of using nuclear weapons in Europe as well; special - psychological, unconventional and counterinsurgency operations. The second option was assigned the highest rank as well as the greatest probability. Thus, it was assumed that the NATO member states could be the first to use nuclear weapons (Kissinger, 2002) Importantly, at the turn of the 1970s and 1980s, the concept of extended deterrence was introduced into American military doctrine, which indicated the threat of using nuclear weapons against the unacceptable by the USA, nonnuclear actions of a potential enemy. The conditio sine qua non of attaining this goal was defined as gaining the U.S. military advantage over the USSR. The concept of one war plus also emerged, which was the opposite of the concept of war and a half. One war plus assumed that the U.S. armed forces should be prepared to wage two kinds of war, one intensive but short war in Europe (about 30 days), which would result in a U.S. victory or turn into a nuclear conflict, and the other one, in another area that is vital to U.S. interests. Due to the constantly growing dependence of Western countries on oil from the Middle East region, military decision-makers in the USA assumed that the most likely place of an East-West confrontation would be this part of the globe, especially the Persian Gulf sub-region. The last of the U.S. Cold War military doctrines, based on the concept of horizontal escalation promoted by the Ronald Reagan administration, assumed that a potential threat to U.S. security should be sought with the same probability in Europe as in other parts of the globe, especially in the Persian Gulf or the Far East. This doctrine was based on the following premises: rejection of détente as the basis of the world order; the growing importance of power as a factor in the implementation of foreign policy; expansion of ideological and moral motivations in justifying foreign and military policy; the use of scientific and technical progress to ensure the U.S. military advantage over the USSR and the Warsaw Pact; subordinating the dialogue with the USSR to efforts to regain the position of the only superpower (Reich, 1980). Under the military doctrine adopted by the Ronald Reagan administration, the number of theaters of war could not be precisely quantified. The defense platform was to be the U.S. armed forces prepared to wage a long conventional war, on the scale of the Korean War 
and even the Second World War. The use of nuclear weapons was not excluded during its course. It was emphasized that the USA would not hesitate to use this type of weapon as the first party (Hubel, 1995).

When introducing the essence of subjective intra-American determinants, it is also worth pointing to the changing model of American society and the dominant systems of beliefs and values. Kenneth Dexter Miller wrote:

We love our land. We love its scenic beauties, its gleaming cities, its broad highways, its gigantic factories and mills, its towering office buildings, its spacious farms and plantations. We love our home, be it farmhouse or palatial mansion, city flat or suburban villa. But what makes America America to us are its people (Miller, 1943).

Importantly, then, there were no deep ideological conflicts in American society during the Cold War. Across divisions, there was agreement on the core values that were widely accepted and deeply entrenched among Americans. Since the inception of the United States as a state, civil religion, understood as a fusion of religion and patriotism (Williams, 2013), has become dominant, which allows for building a conviction in the uniqueness, mission and a kind of messianism of the United States in the world (McKay, 1994).

As Tadeusz Żyro noted:

"Civil religion" creates a set of images specific for the United States, aimed at embedding national symbols into the collective imagination. [...] The arsenal of means which enable influencing social mindset includes three great sets of collective imaginations: utopia, ideology, and myth (Żyro, 2002).

Interestingly, during the Cold War, American political conservatism stood above divisions. This state of affairs was reflected in the conducted foreign policy, which reached ideological consensus. Virtually until the 1980s, there was no such a thing as a strictly conservative or liberal foreign policy. This was not the subject of a dispute between conservatives and liberals who were traditionally linked by anti-communism, and the position that détente should not be the main determinant of the USA attitude towards the USSR. Thus, messianism and the historical mission of the USA during the Cold War was understood primarily as defending the world against the expansion of communist ideology and supporting free nations, the values offered by the democratic system, and the broadly understood protection of human rights. This was one of the main, albeit idealistic, determinants of the U.S. foreign policy during the Cold War.

Coming to an end of the analysis of the subjective determinants of American foreign policy, it is necessary to emphasize the importance of the optimistic idea of the American Dream, which was revived since the 1960s - the belief in prosperity and the possibility of achieving it through hard work - the myth of America as the Promised Land. As a consequence, the American Dream became the spiritus movens of, on the one hand, the development of the civil rights movement in American society (the actions of Martin Luther King), the birth 
of the feminist movement, and on the other, an inspiration for the expansion of conformist behavior, the sexual revolution, the disappearance of elites and value systems, finally the emergence of mass society and the domination of mass culture, which over time belittled the ideals previously guiding American society.

\section{Conclusions}

The Second World War was the greatest challenge for the United States to its own might, forces, means and will to engage globally and abandon the doctrine of the fifth American president James Monroe - the isolationism. From the Second World War, the United States emerged as a superpower capable of expansion and imposing its own political and economic solutions in all regions of the world. The USA has become dominant on four leading levels: political, economic, military, and cultural. A number of intra-American conditions, including a favorable geopolitical location, high position in terms of the size of the territory and population, rapid scientific and technical progress, encompassing the military field and the arms race in space, as well as the consensus of political elites in the matter of foreign policy and the fact that the greatest threat to the U.S. security remains the USSR and the possibility of spreading communist ideology, enabled the United States to effectively compete with the other superpower in a bipolar system.

Therefore, the Cold War shaped the foreign policy of the United States, influenced the attitudes of American society, consolidated patriotic values, raised the rank of civil religion, but also more broadly - shaped a new international order. The USA undoubtedly won the confrontation with the expansive superpower of the USSR, and at the beginning of the last decade of the 20th century it remained the only superpower and invincible hegemon capable of domination on a global scale. Thus, the dissolution of the USSR and the collapse of the Eastern Bloc meant that the enemy that had shaped American foreign policy for several decades disappeared, but its spirit remained. The U.S. victory in the Cold War competition did not therefore mean an unconditional victory. The new international order that was taking shape at the turn of the 20th and 21st centuries brought many new challenges and threats to American political decisionmakers. First of all, new rival powers have emerged, among which China has become the most competitive (especially in the economic field). As it turned out on September 11, 2001, the visible and yet predictable enemy that was the USSR was replaced by an invisible and completely unpredictable one - Islamic terrorism and jihadism, for which the USA and the ongoing cola-colonization of the world are the embodiment of all evil. 


\section{Resources}

Ambrose, S.E. (1993). Eisenhower. Żotnierz i prezydent. Warszawa: Państwowy Instytut Wydawniczy.

Ball, S.J. (1998). The Cold War. An International History, 1947-1991. London, New York, Sydney, Auckland: Arnold/Hodder Headline Group.

Bartlett. Ch. (1997). Konflikt globalny. Międzynarodowa rywalizacja wielkich mocarstw w latach 19880 - 1990. Wrocław-Warszawa-Kraków: Zakład Narodowy im. Ossolińskich.

Bartnicki, A., Michałek K., Rusinowa I. (2001). Encyklopedia Historii Stanów Zjednoczonych Ameryki. Dzieje polityczne (od Deklaracji Niepodległości do współczesności). Warszawa: Egross, Morex.

Berezowski, M. (2001), Krótka Encyklopedia USA. Warszawa: Dom Wydawniczy Elipsa.

Bowles N. (1998). Government and Politics of the United States. London: Macmillan Press Ltd.

Bógdoł-Brzezińska, A. (2001). Globalizacja polityki Stanów Zjednoczonych 19451949. Warszawa: Oficyna Wydawnicza ASPRA-JR.

Brzeziński, Z. (1966). Europa bez podziału. Właściwe zadanie polityki amerykańskiej w Europie. Londyn: Polonia Book Fund.

Cole, W.S. (1968). An Interpretive History of American Foreign Relations. Homewood, Illinois: University of Marland, The Dorsey Press.

Cooley, J.K. (1991). Payback: America's Long War in the Middle East. London: Brassey's, Macmillan.

Cordesman, A.H. (1987). The Iran-Iraq War and Western Security 1984-1987. Strategic Implications and Policy Options. London: Martinus Nijhoff Publisher.

Davidson, R., Oleszek, W. (1994), Kongres i kongresmani. Warszawa: Wydawnictwo Sejmowe.

Dobrzycki, W. (2000). Stosunki międzynarodowe w Ameryce Lacińskiej. Historia $i$ współczesność. Warszawa: Scholar.

11 September. Religious Perspectives on the Causes and Consequences (2002). Ed. I. Markham, I. M. Abu-Rabi. Oxford: Oneworld.

Gaddis, J.L. (1997). Teraz już wiemy... Nowa historia zimnej wojny. Warszawa: Amber.

Growth of U.S. population. https://www.theusaonline.com/people/growth.htm

Halliday F. (2005). The Middle East In International Relations. Power, Politics and Ideology. Cambridge: Cambridge University Press.

Herrera, R., Cicchini, J. (2013). Some notes about the U.S. military bases and personnel abroad, Journal of Innovation Economics \& Management, Vol. 2, No. 12 , $127-132$.

Higgs, R. (1994). The Cold War Economy. Opportunity Costs, Ideology, and the Politics of Crisis. Independent Institute, Jule 1, 1994. Downloaded from: https:// www.independent.org/publications/article.asp?id=1297 (access: 16.09.2020). 
Historia polityczna świata XX wieku 1901-1945 (2004). red. M. Mankowicz, Kraków: Wydawnictwo Uniwersytetu Jagiellońskiego.

Hofman, I. (2009), The Attributes of the Fourth Estate. In the Area of Medial Theories and Politics. Polish Political Science Yearbook, Vol. XXXVIII, 47-57.

Holzer, J. (2000). Komunizm w Europie. Warszawa: Bellona.

Horowitz, I.L. (1977). Ideology and utopia In the United States 1956-1976. London, Oxford, New York: Oxford University Press.

Hubel, H. (1995). Das Ende des Kalten Kriegs im Orient. Die USA, die Sowjetunion und die Konflikte in Afghanistan, am Golf und Nahen Osten, 1979-1991. Auswirkungen für Europa und Deutschland. München: R. Oldenbourg Verlang.

Huntington, S.P. (1986). American Military Strategy. Policy Papers In International Affairs, 13. Institute of International Studies. Berkley: University of California.

Huntington, S.P. (1999). The lonely superpower. Foreign Affairs, No. 35, 35-49.

Iranian Perspectives oni the Iran-Iraq War (1997). ed. F. Rajaee, Gainesville: University Press of Florida.

Jaskuła, Ł (2014). Zbędny arsenat. Polityka nuklearna Stanów Zjednoczonych po zakończeniu zimnej wojny. Gdańsk: Wydawnictwo Uniwersytetu Gdańskiego.

Jones, M.A. (2002). Historia USA. Gdańsk: Marabut.

Khara, N.K. (2018). Determinants of Foreign Policy: A Global Perspective. International Journal of Research and Analytical Reviews, Vol. 5, Issue 3, 107-108.

Kissinger, H. (2002). Dyplomacja. Warszawa: Philips Wilson.

Kiwerska, J. (1995). Między izolacjonizmem a zaangażowaniem. Europa w polityce Stanów Zjednoczonych od Wilsona do Roosevelta. Poznań: Instytut Zachodni.

Kiwerska, J. (1999). Słownik prezydentów amerykańskich. Poznań: Wydawnictwo Poznańskie.

Kokxhorn, N. (1976). Oil and Politics. The domestic roots of US expansion in the Middle East. Berlin: Peter Lang Frankfurt/M. Herbert Lang Bern.

Konstytucja Stanów Zjednoczonych Ameryki (2002). Warszawa: Wydawnictwo Sejmowe.

Krauthammer, Ch. (2002). The Unipolar Moment Revisited. The National Interest, No. 3, 5-17.

Kutler, S.I. (1994). In the Shadow of Watergate: Legal, Political, and Cultural Implications. Nova Law Review, Vol. 18, Issue 3, 1744-1763.

Lafeber, W. (1967). America, Russia, and the Cold War 1945-1966. New York, London, Sydney: John Wiley \& Sons.

Lenczowski, G. (1990). American Presidents and the Middle East, American Presidents and the Middle East. London: Durham.

Łastawski, K. (2004). Od idei do integracji europejskiej. Od najdawniejszych idei do Unii 25 państw. Warszawa: Wydawnictwo Wyższej Szkoły Pedagogicznej TWP.

Łoś-Nowak, T. (2000). Stosunki międzynarodowe. Teorie - systemy - uczestnicy. Wrocław: Wydawnictwo Uniwersytetu Wrocławskiego.

Malendowski W. (1994). Zimna wojna. Sprzeczności, konflikty i punkty kulminacyjne $w$ radziecko-amerykańskiej rywalizacji. Poznań: Wyd. INPiD. 
Mania, A. (2019). Department of State i Foreign Service w polityce zagranicznej USA lat goracej i zimnej wojny 1939-1989. Kraków: Wydawnictwo Unwersytetu Jagiellońskiego.

McCauley, M. (2008). The Origins of the Cold War. London and New York: Longman.

McKay, D. (1994). Politics and Power in the USA. London: Penguin Books.

Michałek, K. (2004). Amerykańskie stulecie. Historia Stanów Zjednoczonych Ameryki 1900_-2001. Warszawa: Mada.

Michałek, K. (1993). Na drodze ku potędze. Historia Stanów Zjednoczonych Ameryki 1861-1945. Warszawa: Książka i Wiedza.

Miller, K.D. (1943). We who are America. New York: Friendship Press.

Nowik, N. (1985). Encounter with Reality: Reagan and The Middle East during the First Term. Colorado: Boulder, Westview Press.

Oezel, Y. (2015). The Impact of the "Unipolar Moment" on US Foreign Policies in the Mid-East. Sep 13 2015. Downloaded from: http://www.e-ir.info/2015/09/13/ the-impact-of-the-unipolar-moment-on-us-foreign-policies-in-the-mid-east/ (access: 8.09.2020).

Ohtomo, T. (2012). Understanding U.S. Overseas Military Presence after World War II. Japanese Studies, Vol. 4, 18-26.

Omitoogun, W., Sköns, E. (2007). Military expenditure data: A 40-year overview. SIPRI Yearbook, 271-280.

Organizacje $w$ stosunkach międzynarodowych. Istota - mechanizmy działania zasięg (2004). red. T. Łoś-Nowak, Wrocław: Wydawnictwo Uniwersytetu Wrocławskiego.

Pastusiak, L. (2005). Prezydenci Stanów Zjednoczonych Ameryki. Warszawa: Iskry.

Perlo-Freemen, S. (2016). 65 years of military spending: Trends in SIPRI's new data, SIPRI, 21 November, Downloaded from: https://www.sipri.org/commentary/ blog/2016/65-years-military-spending (access: 12.09.20202).

Skurowski, P. (1997). Od Waszyngtona do Clintona. Antologia amerykańskich esejów politycznych. Warszawa: Instytut Polityczny.

Stivers, W. (1986). America's Confrontation with Revolutionary Change In the Middle East, 1948-83. Hong Kong: MacMillan Press Ltd.

Stosunki międzynarodowe. Geneza, struktura, funkcjonowanie (2001). red. E. Haliżak, R. Kuźniar, Warszawa: Wydawnictwo Uniwersytetu Warszawskiego.

Superpower Intervention in the Persian Gulf (1992). ed. R.B. Byers, D. LeytonBrown, Toronto: The Canadian Institute of Strategic Studies.

Tarock, A. (1998). The Superpowers' Involvement in the Iran-Iraq War. New York: Nova Science Publishers, Inc., Commack

Tensley, B. (2019). How the American Dream went from meaning equality to meaning capitalism, July 24. Downloaded from: https://psmag.com/ideas/how-theamerican-dream-went-from-meaning-equality-to-meaning-capitalism-sarahchurchwell (access: 12.09.2020).

The Cold War. A History In Documents and Eyewitness Accounts (2003). ed. J.M. Hanhimäki, O.A. Westad, Oxford: Oxford University Press.

The Middle East and the United States. Perceptions and Policies (1980). ed. H. Shaker, I. Rabinovich, New Brunswick, London: Transaction Books. 
U.S. Role in the World: Background and Issues for Congress (2020). Congressional Research Service Report, 30 October. Downloaded from: https://fas.org/sgp/crs/ row/R44891.pdf (access: 12.09.2020).

Williams, R.H. (2013). Civil Religion and the Cultural Politics of National Identity in Obama's America. Chicago: Lyola University Chicago.

Wstęp do teorii polityki zagranicznej państwa (2004). red. R. Zięba, Toruń: Wydawnictwo Adam Marszałek.

Zarys wspótczesnych stosunków międzynarodowych (2001). red. E. Cziomer, L.W. Zyblikiewicz, Warszawa-Kraków: PWN.

Zyblikiewicz L. (2004). USA. Warszawa: Trio.

Żyro T. (2002). Ideologia Americana. U źródet przekonań politycznych. Warszawa: ŁośGraf. 